\title{
Analisis Tingkat Kognitif Soal pada Buku Kemendikbud Revisi 2018 Materi Persamaan dan Fungsi Kuadrat
}

\author{
Topan Agung Pinilih Rahmat Illahi, Nurul Astuty Yensy B, Ringki Agustinsa
}

(C) 2021 JEMS (Jurnal Edukasi Matematika dan Sains)

This is an open access article under the CC-BY-SA license (https://creativecommons.org/licenses/bysa/4.0/) ISSN 2337-9049 (print), ISSN 2502-4671 (online)

\begin{abstract}
Abstrak:
Penelitian ini bertujuan untuk mengetahui sebaran tingkat kognitif soal latihan dan soal uji kompetensi materi Persamaan dan Fungsi Kuadrat pada Buku Sekolah Elektronik (BSE) Matematika SMP/MTs Kelas IX Kurikulum 2013 terbitan Kemendikbud edisi revii 2018 berdasarkan Taksonomi Bloom Revisi. Taksonomi Bloom revisi yang digunakan adalah pada proses kognitif yang terdiri dari: C1-mengingat, C2memahami, C3-mengaplikasikan, C4-menganalisis, C5mengevaluasi, dan C6-mencipta. Jenis penelitian ini berupa penelitian deskriptif dengan pendekatan kuantitatif. Sumber data yang diambil pada penelitian ini adalah pada soal Latihan dan soal Uji Kompetensi. Soal Latihan yang di analisis berjumlah 49 soal dengan 72 pertanyaan dan soal Uji Kompetensi yang di analisis berjumlah 30 soal dengan 35 pertanyaan. Pada soal Latihan diperoleh tingkat kognitif C2memahami sebanyak 6 pertanyaan $(8,33 \%)$, C3mengaplikasikan sebanyak 61 pertanyaan $(84,72 \%)$, C4menganalisis sebanyak 4 pertanyaan $(5,55 \%)$, dan C5mengevaluasi sebanyak 1 pertanyaan $(1,4 \%)$, serta belum terdapat soal dengan tingkat kognitif C1-memahami dan C6mencipta. Sedangkan pada soal Uji Kompetensi diperoleh tingkat kognitif C2-memahami sebanyak 1 pertanyaan (2,85\%), C3-mengaplikasikan sebanyak 31 pertanyaan $(88,57 \%)$, C4menganalisis sebanyak 2 pertanyaan $(5,71 \%)$, dan C5mengevaluasi sebanyak 1 pertanyaan $(2,85 \%)$, serta belum terdapat soal dengan tingkat kognitif C1-memahami dan C6mencipta. Dengan demikian, hasil yang diperoleh menyatakan bahwa soal-soal yang diberikan belum cukup proporsional.
\end{abstract}

Kata Kunci : "Buku Sekolah Elektronik (BSE)", "Soal, Taksonomi Bloom Revisi”, “Tingkat Kognitif.”

\begin{abstract}
:
This study aims to determine the distribution of cognitive levels of practice questions and competency test questions for Quadratic Equations and Functions in Electronic Mathematics Textbooks (BSE) for Junior High School 9th Grade Curriculum 2013 published by the Ministry of Education and Culture in the Revised 2018 edition based on Bloom's Taxonomy Revision. Bloom's taxonomy revision used is cognitive processes consisting of: C1-remembering, C2-understanding, C3-applying, C4-analyzing, C5-evaluating, and C6-creating. This type of research was descriptive research with a qualitative approach. Sources of data taken in this study were the practice questions and competency test questions. The Practice Questions analyzed were 49 problems with 72 questions and the Competency Test questions analyzed were 30 problems with 35 questions. In practice questions, the data obtained of cognitive level C2-understand was 6 questions $(8.33 \%)$, C3-applying was 61 questions $(84.72 \%)$, C4-analyze was 4 questions $(5.55 \%)$, and C5-evaluate was 1 question (1.4\%), and there were no questions with cognitive levels of C1-understanding and C6creating. While on the Competency Test questions, the data obtained of cognitive level C2-understanding was 1 question (2.85\%), C3-applying was 31 questions $(88.57 \%)$, C4-analyzing was 2 questions $(5.71 \%)$, and C5- evaluated was 1 question (2.85\%), and there were no questions with cognitive levels of C1-understanding and C6-creating. Thus, the results that are obtained state the issues given are not proportionate enough.
\end{abstract}

Keywords : "Bloom's Taxonomy Revision", "Cognitive Level", "Electronic School Book (BSE)", "Questions."

\section{Pendahuluan}

Matematika ialah cabang pokok dari suatu ilmu yang digunakan dalam bermacam disiplin

\author{
Topan Agung Pinilih Rahmat Illahi, Universitas Bengkulu
}

Topanagung06.ri@gmail.com

Nurul Astuty Yensy, Universitas Bengkulu

nurulastutyyensy@unib,ac,id

Ringki Agustinsa, Universitas Bengkulu

ringki@unib.ac.id 
pelaksanaan, serta sebab watak nya yang umum sehingga jadi dasar dalam pertumbuhan teknologi modern, tidak heran matematika senantiasa jadi perihal yang sangat utama (Amelia, Susanto, \& Fatahillah., 2016). Kita mengenali kalau permasalahan pembelajaran di Indonesia kerap kali diperbincangkan. Partisipan didik di Indonesia masih mempunyai banyak kekurangan serta kelemahan dalam pemahaman konsep semacam yang diselenggarakan oleh Trends in International Mathematics and Scienc Study (TIMSS). TIMSS ialah lembaga yang melaksanakan riset tentang keahlian matematika serta sains dari segala dunia buat menampilkan serta menarangkan faktor- faktor pembeda antar negeri serta di dalam sesuatu negeri. Semacam pada tahun 2015, Indonesia turut serta pada riset internasional TIMSS dengan mengirim anak kelas 4 sekolah dasar, didapati Indonesia terletak pada peringkat 44 dari 49 negeri. Skor rata- rata yang diperoleh sebesar 397 poin dari rata- rata negara lain yang mendapatkan 500 poin, di momen berikutnya pada tahun 2019 Indonesia tidak mengirimkan delegasi lagi (Mullis, I. V. S., Martin, M. O., Foy, P., Kelly, D. L., \& Fishbein, B., 2012: 45). Perihal ini meyakinkan kalau, ada banyak aspek pemicu rendahnya prestasi peserta didik, salah satunya pada pemahaman konsep (aspek internal) serta pada sarana belajar yang butuh ditingkatkan (aspek eksternal). Soal- soal yang diberikan oleh TIMSS ialah soal berpikir tingkat tinggi (Wu, 2009: 3).

Salah satunya langkah pemerintah untuk meningkatkan mutu pendidikan yaitu dengan memudahkan buku pelajaran dan akses buku ajar matematika. Kondisi yang mendorong untuk kemajuan teknologi seperti kebutuhan elektronik yaitu menimbulkan terobosan baru dari pemerintah untuk membeli hak cipta buku teks dari penulis atau penerbit. Kemudian buku tersebut disajikan dalam bentuk elektronik yang biasa disebut dengan Buku Sekolah Elektronik (BSE). Buku BSE sudah banyak tersebar di media elektronik dan website, karena untuk disajikan lebih praktis, sehingga bisa kita dapatkan dengan mengunduh gratis di internet.

Soal-soal yang disediakan pada buku BSE memiliki tingkatan-tingkatan yang disebut dengan tingkat kognitif. Soal yang biasa ditampilkan adalah soal latihan dan soal uji kompetensi. Soal tersebut telah dirancang atau tersusun sesuai dengan kemampuan peserta didik, apakah soal itu bervariasi tingkatannya, atau tidak. Sehingga, kita dapat mengetahui dari soal-soal yang tidak merata itulah menjadi kelemahan sebuah buku teks yang digunakan terutama dalam mendorong peserta didik tersebut untuk berpikir tingkat tinggi, seperti berpikir kritis, kreatif dan analitis (Masduki, M.R. Irawan, \& D.Y. Prihantoro. A., 2013: 15).

Soal latihan dan soal uji kompetensi ini sering sekali disajikan oleh pengajar sebagai bahan evaluasi pembelajaran. Soal latihan dan uji kompetensi tersebut diambil dari buku, biasanya terdapat pada akhir setiap subbab atau bagian akhir bab buku pembelajaran tersebut. Tujuan pada soal latihan yaitu untuk mengevaluasi pembelajaran pada setiap subbab dan melatih peserta didik untuk terbiasa mengerjakan soal-soal. Sedangkan, tujuan pada soal uji kompetensi yaitu untuk mengevaluasi setiap materi yang telah diberikan di akhir bab, sehingga faktor terpenting dalam belajar adalah adanya latihan yang kontinu (Puryati, 2017: 192). Soal yang memenuhi adalah soal yang tidak terlalu sulit secara keseluruhan, atau soal yang terlalu mudah secara keseluruhan. Hal ini berdasarkan standar Badan Standar Nasional Pendidikan tahun 2014, yaitu harus terdapat soal yang bisa mengarahkan peserta didik untuk berpikir tingkat tinggi, yaitu; menganalisis, mensintesis, mengevaluasi, dan mencipta (BSNP, 2014). Ketika soal-soal yang dikerjakan oleh peserta didik terlalu mudah, maka peserta didik merasa dirinya sudah hebat dan cenderung menyepelekan soal-soal yang lain. Sebaliknya, ketika soalsoal yan di sajikan terlalu sulit, maka peserta didik cepat putus asa dan menganggap dirinya tidak mampu bahkan enggan berhadapan dengan soal-soal matematika. Sehingga, perlu 
adanya dilakukan analisis tingkat kognitif soal latihan dan uji kompetensi yang biasa sering diberikan oleh pengajar kepada peserta didik. Tingkatan kognitif ini adalah salah satu aspek yang terdapat pada taksonomi Bloom revisi atau kadang orang menyebutnya taksonomi pendidikan Bloom (Anderson \& Krathwohl, 2010).

Taksonomi Bloom merupakan kerangka berpikir khusus yang hanya mempunyai satu dimensi. Sedangkan, taksonomi Bloom revisi merupakan kerangka berpikir khusus yang memiliki dua dimensi, yaitu proses kognitif dan pengetahuan (Anderson \& Krathwohl, 2010: 6). Diharapkan pada kurikulum 2013 terdapat keseimbangan aspek atau ranah pembelajaran, yaitu kognitif, afektif, dan psikomotor. Hal ini mengartikan bahwa ketika guru dan peserta didik tersebut mengetahui tingkatan soal-soal yang diberikan, maka akan ada persiapan dan kemudahan didalamnya. Apalagi taksonomi ini sangat membantu guru untuk menilai kesanggupan atau kemampuan peserta didik dalam mengerti yang dipelajarinya. Sehingga, hal ini sangat penting untuk dilakukan penelitian analisis tingkat kognitif soal (Anderson \& Krathwohl, 2010: 98).

Selain itu, peneliti tertarik melakukan penelitian ini karena hasil penelitian dari Kurniawan (2020) pada buku ajar matematika kurikulum 2013 edisi revisi 2017 masih berada pada kurang variatif dengan didominasi pada tingkat kognitif C1-mengingat sebesar 52,63\%, sedangkan pada C4-menganalisis, C5-mengevaluasi, dan C6-mencipta tidak terdapat satu pun soal dengan kategori tersebut (Kurniawan, 2020: 10). Disisi lain, Manfaat ditentukannya tingkat kognitif soal yaitu untuk merenovasi kualitas dan meningkatkan kecerdasan prestasi peserta didik tersebut. Sebaiknya, soal-soal disusun untuk setiap pertanyaannya sesuai dengan kemampuan kognitifnya. Dengan demikian, soal tersebut menjadi berguna untuk pengajar dan peserta didik. Kita lihat manfaatnya bagi peserta didik, mereka mudah saat mengerjakan soal tersebut, karena bisa memprediksi soal yang muncul, karena dilihat dari tingkatannya mulai dari C1mengingat, C2-memahami, C3-mengaplikasikan, C4-menganalisis, C5-mengevaluasi, dan C6mencipta. Sedangkan untuk pengajar, soal tersebut mempermudah mengetahui potensi tingkat kemampuan kognitif peserta didik. Sehingga, soal tersebut perlu dilakukan penelitian atau pengkajian untuk mengetahui tingkat ranah kognitifnya (Anderson \& Krathwohl, 2010: 120134).

Materi yang dipilih pada penelitian ini ialah pada materi persamaan dan fungsi kuadrat kelas IX. Materi tersebut merupakan salah satu materi untuk mengasah kemampuan berpikir tingkat tinggi, dan sebagai prasyarat untuk materi selanjutnya di kelas X SMA, kemudian peneliti memilih materi ini karena belum terdapat pada penelitian sebelumnya mengenai materi ini.

Berdasarkan hal tersebut, maka dilakukan penelitian yang berjudul "Analisis Tingkat Kognitif Soal Pada Buku Kemendikbud Revisi 2018 Materi Persamaan dan Fungsi Kuadrat". Tujuan utama dari penelitian ini adalah untuk mengetahui sebaran tingkat kognitif soal latihan dan soal uji kompetensi pada materi Persamaan dan Fungsi Kuadrat Buku Sekolah Elektronik (BSE) Matematika SMP/MTs Kelas IX Kurikulum 2013 Edisi Revisi 2018 Berdasarkan Taksonomi Bloom Revisi. Penelitian ini bermanfaat bagi peneliti, guru, peserta didik, dan bagi percetakan khususnya di bidang .

\section{Metode}

Jenis penelitian ini adalah penelitian deskriptif kuntitatif, yaitu penelitian yang berusaha untuk mendeskripsikan dan mengintepretasikan sesuatu hal berupa gambaran terhadap obyek 
yang diteliti melalui suatu data sampel sebagaimana adanya (Sugiyono, 2019b: 29). Prosedur penelitian yang dilakukan pada penelitian ini sebagai berikut:

1. Mengumpulkan dan mengidentifikasi sebaran soal latihan dan soal uji kompetensi.

2. Melakukan penyelesaian tiap soal dengan mendeskripsikan penyelesaiannya.

3. Menganalisis tingkat kognitif soal berdasarkan Taksonomi Bloom Revisi.

4. Mengklasifikasikan soal berdasarkan ranah kognitif Taksonomi Bloom Revisi.

5. Melakukan analisis tingkat kognitif soal yang dilakukan oleh teman sejawat.

6. Melakukan analisis persentase soal untuk masing-masing tingkat kognitif, persentase tersebut dibandingkan dengan proporsi yang mendukung pencapaian Kompetensi Dasar.

7. Menarik kesimpulan dan saran.

Sumber data dalam penelitian ini adalah soal latihan dan soal uji kompetensi bab Persamaan dan Fungsi Kuadrat pada Buku Sekolah Elektronik (BSE) Matematika Kelas IX SMP/MTs Kurikulum 2013 terbitan Pusat Kurikulum dan Perbukuan, Balitbang, Kemendikbud karya Subchan, Winarni, Muhmmad Syifa'ul Mufid, Kistosil Fahim,dan Wawan Hafid Syaifudin. Pada soal Latihan, total soal berjumlah 72 pertanyaan, dan soal Uji Kompetensi sebanyak 35 pertanyaan. Sedangkan, total pertanyaan keseluruhan sebanyak 107 pertanyaan.

Metode pengumpulan data menggunakan metode dokumentasi, yaitu proses mengumpulkan data lewat literasi seperti: buku, jurnal, teori, arsip lembar klasifikasi tingkat kognitif oleh peneliti dan teman sejawat, dan lembar validasi kesesuaian soal yang diteliti oleh peneliti dengan teman sejawat. Dalam tingkat kognitif soal diberikan pada Tabel 1. Berikut:

Tabel 1. Daftar Indikator Berdasarkan Taksonomi Bloom Revisi

\begin{tabular}{|c|c|c|}
\hline $\begin{array}{l}\text { Dimensi Proses } \\
\text { Kognitif }\end{array}$ & $\begin{array}{l}\text { Pembagian Dimensi } \\
\text { Proses Kognitif }\end{array}$ & Indikator Soal \\
\hline \multirow[t]{2}{*}{ Mengingat (C1) } & $\begin{array}{ll}\text { a. } & \text { Mengenali } \\
& \text { (Recognizing) }\end{array}$ & $\begin{array}{l}\text { 1) Berisi tentang pendefinisian suatu istilah } \\
\text { 2) Berisi tentang suatu lambang/simbol, sifat-sifat, } \\
\text { atau informasi }\end{array}$ \\
\hline & b. Mengingat (Recalling) & $\begin{array}{l}\text { 1) Mengingat bentuk penyajian sifat-sifat yang } \\
\text { saling berkaitan } \\
\text { 2) Mengambil tahapan pengingatan dan penyajian } \\
\text { suatu cara atau gambaran }\end{array}$ \\
\hline \multirow[t]{5}{*}{ Memahami (C2) } & a. Menafsirkan & $\begin{array}{l}\text { Mengambil proses penyajian bentuk data satu } \\
\text { dengan data lainnya } \\
\text { 2) Mengambil proses data yang sudah ada atau } \\
\text { sudah ditetapkan }\end{array}$ \\
\hline & b. Memberikan contoh & $\begin{array}{l}\text { Mengambil tahapan menghubungkan sifat atau } \\
\text { ciri informasi dari soal dengan informasi yang } \\
\text { kejadian sehari-hari atau kejadian yang umum. } \\
\text { Peserta didik memisalkan fungsi kuadrat dengan } \\
\text { rumus umum fungsi kuadrat }\end{array}$ \\
\hline & c. Mengklasifikasikan & $\begin{array}{l}\text { Mencocokan dan menggolongkan sifat atau ciri } \\
\text { yang sama dari informasi yang diberikan }\end{array}$ \\
\hline & d. Meringkas & $\begin{array}{l}\text { Menarik proses pemilihan atau pengambilan satu } \\
\text { informasi yang dapat mewakili seluruh informasi }\end{array}$ \\
\hline & e. $\quad$ Menarik inferensi & $\begin{array}{l}\text { 1) Menarik proses pemilihan atau pengambilan inti } \\
\text { informasi } \\
\text { 2) Menghubungkan setiap titik koordinat atau } \\
\text { informasi pada soal yang diberikan menjadi sketsa } \\
\text { grafik }\end{array}$ \\
\hline
\end{tabular}




\begin{tabular}{|c|c|c|}
\hline $\begin{array}{l}\text { Dimensi Proses } \\
\text { Kognitif }\end{array}$ & $\begin{array}{l}\text { Pembagian Dimensi } \\
\text { Proses Kognitif }\end{array}$ & Indikator Soal \\
\hline & f. Membandingkan & $\begin{array}{l}\text { 1) Menarik proses mengubungkan persamaan dan } \\
\text { perbedaan sifat atau ciri dari informasi persamaan } \\
\text { dan fungsi kuadrat }\end{array}$ \\
\hline & & Menyelesaikan perbandingan antara dua grafik \\
\hline & g. Menjelaskan & $\begin{array}{l}\text { Memuat penjabaran mengenai sebab-akibat antar } \\
\text { informasi dalam satu sistem pada persamaan dan } \\
\text { fungsi kuadrat. }\end{array}$ \\
\hline & & $\begin{array}{l}\text { Kemampuan yang digunakan untuk } \\
\text { mengkonstruksikan makna dari materi persamaan } \\
\text { dan fungsi kuadrat. }\end{array}$ \\
\hline \multirow[t]{7}{*}{$\begin{array}{l}\text { Mengaplikasik an } \\
\text { (C3) }\end{array}$} & a. Menjalankan & $\begin{array}{l}\text { 1) Proses suatu operasi hitung dengan rumus yang } \\
\text { ada dengan langkah-langkah penyelesaian yang } \\
\text { familier }\end{array}$ \\
\hline & & $\begin{array}{l}\text { Proses substitusi atau memasukkan bilangan ke } \\
\text { rumus yang telah ditetapkan. }\end{array}$ \\
\hline & & $\begin{array}{l}\text { 3) Dapat menyelesaikan penjumlahan, } \\
\text { pengurangan, pembagian, perkalian dari } \\
\text { persamaan dan fungsi kuadrat }\end{array}$ \\
\hline & & $\begin{array}{l}\text { Mengidentifikasikan langkah-langkah yang telah } \\
\text { ditetapkan secara runut dengan modifikasi atau } \\
\text { rumus yang diberikan. }\end{array}$ \\
\hline & $\begin{array}{l}\text { b. Mengimplementasika } \\
\mathrm{n}\end{array}$ & $\begin{array}{l}\text { 1) proses penyelesaian dengan pemodifikasian } \\
\text { prosedur pada rumus yang familier }\end{array}$ \\
\hline & & $\begin{array}{l}\text { Menyelesaikan perhitungan dengan runut dan } \\
\text { dengan perencanaan dari rumus yang ada pada } \\
\text { persamaan kuadrat, fungsi kuadrat, ataupun } \\
\text { dalam membuat grafik. }\end{array}$ \\
\hline & & $\begin{array}{l}\text { Memasukkan nilai-nilai yang didapat dari } \\
\text { persamaan ke rumus yang familier. }\end{array}$ \\
\hline \multirow[t]{8}{*}{ Menganalisis (C4) } & a. Membedakan & $\begin{array}{l}\text { Memilah suatu bentuk setelah dilakukannya } \\
\text { analisis terhadap bentuk persamaan atau grafik } \\
\text { yang diperoleh }\end{array}$ \\
\hline & & $\begin{array}{l}\text { menyelesaikan tahapan merinci sifat atau ciri } \\
\text { dari sebuah bentuk yang ada }\end{array}$ \\
\hline & & $\begin{array}{l}\text { mengidentifikasikan perbedaan dari pengamatan } \\
\text { yang telah dihitung dengan konsep persamaan } \\
\text { kuadrat }\end{array}$ \\
\hline & b. Mengorganisasikan & $\begin{array}{l}\text { mengidentifikasi atau mengelompokkan sifat } \\
\text { atau ciri sturuktur yang baru persamaan fungsi } \\
\text { kuadrat }\end{array}$ \\
\hline & & $\begin{array}{l}\text { melakukan beberapa prosedur yang ada dari } \\
\text { persamaan fungsi kuadrat }\end{array}$ \\
\hline & & $\begin{array}{l}\text { menggabungkan beberapa konsep atau rumus } \\
\text { yang muncul dari informasi data }\end{array}$ \\
\hline & $\mathrm{Me}$ & Peserta didik dapat memuat pesan dari informasi \\
\hline & $\begin{array}{l}\text { ndekontruksikan/Me } \\
\text { nemukan Pesan } \\
\text { Tersirat }\end{array}$ & $\begin{array}{l}\text { Memuat maksud dari pesan yang diberikan hasil } \\
\text { proses menganalisis }\end{array}$ \\
\hline
\end{tabular}




\begin{tabular}{|c|c|c|}
\hline $\begin{array}{l}\text { Dimensi Proses } \\
\text { Kognitif }\end{array}$ & $\begin{array}{l}\text { Pembagian Dimensi } \\
\text { Proses Kognitif }\end{array}$ & Indikator Soal \\
\hline \multirow[t]{2}{*}{ Mengevaluasi (C5) } & a. Memeriksa & $\begin{array}{l}\text { 1) menyelidiki sebuah kekonsistenan atau } \\
\text { pembuktian cara lain suatu struktur dengan } \\
\text { menggunakan berbagai penyelesaian }\end{array}$ \\
\hline & b. Mengritisi & $\begin{array}{l}\text { Peserta didik memberikan pendapat atas soal } \\
\text { yang diberikan } \\
\text { 2) Mengupayakan adanya penilaian atas soal yang } \\
\text { diberikan }\end{array}$ \\
\hline \multirow[t]{3}{*}{ Mencipta (C6) } & a. Membuat & $\begin{array}{l}\text { 1) Peserta didik mengupayakan sebuah dugaan } \\
\text { penyelesaian yang dilewati setelah proses evaluasi }\end{array}$ \\
\hline & b. Merencanakan & 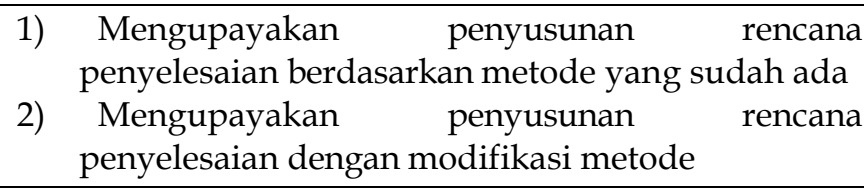 \\
\hline & c. Memproduksi & $\begin{array}{l}\text { Peserta didik dapat memuat sebuah rumus baru } \\
\text { dari hasil evaluasi dengan tindakan atau kegiatan } \\
\text { penyelesaian yang telah disusun. } \\
\text { Peserta didik dapat menghasilkan sesuatu hal } \\
\text { yang kongkrit atau nyata }\end{array}$ \\
\hline
\end{tabular}

Sumber: Modifikasi dari Anderson \& Krathwohl Selanjutnya, menghitung persentase tingkat kognitif soa dengan menggunakan rumus:

$$
P_{i}=\frac{N_{i}}{N} \times 100 \%
$$

Sumber: (Modifikasi dari Riduwan, 2014: 28)

Keterangan:

$\mathrm{Pi}=$ Persentase banyaknya soal yang terkategorikan dalam tingkat kognitif berdasarkan Taksonomi Bloom edisi Revisi

$\mathrm{Ni}=$ Banyak soal latihan atau soal uji kompetensiyang terkategorikan dalam tingkat proses kognitif berdasarkan Taksonomi Bloom hasil revisi $(i=$ tingkat proses kognitif C1 (Mengingat), C2 (Memahami), C3 (Mengaplikasikan), C4 (Menganalisis), C5 (Mengevaluasi), dan C6 (Mencipta)).

$\mathrm{N}=$ Total pertanyaan.

Setelah itu menghitung keeratan persepsi antara peneliti dengan teman sejawat yaitu dengan koefisien korelasi spearman Rank yang dapat dihitung menggunakan SPSS atau menggunakan rumus korelasi dan tabel koefisien korelasinya, yakni:

$$
\rho=1-\frac{6 \sum b_{i}^{2}}{n\left(n^{2}-1\right)}
$$

Keterangan:

$$
\begin{aligned}
& \rho=\text { koefisien Spearman Rank } \quad n=\text { Banyak } \\
& b_{i}=\text { Selisih antar rangking }
\end{aligned}
$$


Tabel 2. Pedoman Memberikan Interpretasi Koefisien Korelasi (r)

\begin{tabular}{cc}
\hline Interval koefisien (r) & Tingkat Hubungan/Kriteria \\
\hline $0,00-0,199$ & Sangat Rendah \\
$0,20-0,399$ & Rendah \\
$0,40-0,599$ & Sedang \\
$0,60-0,799$ & Kuat \\
$0,80-1,000$ & Sangat Kuat \\
\hline
\end{tabular}

Sumber: (Sugiyono, 2019a: 248)

Pada tabel di atas, korelasi yang digunakan adalah pada interval $0,40-1,00$, yaitu minimal pada kriteria sedang, kuat, hingga sangat kuat. Jika koefisien (r) berada pada interval tersebut, maka level kognitif soal yang dianalisis itu sesuai. Tetapi, jika kurang dari 0,4 maka belum sesuai.

\section{Hasil dan Pembahasan}

Hasil penelitian akan dijabarkan menjadi 3 poin, yaitu: (1) Deskripsi Pelaksanaan Penelitian, (2) Deskripsi Hasil Penelitian, dan (3) Rekapan Kesesuaian Analisis Level Kognitif Soal oleh Teman Sejawat. Secara detail, akan di jelaskan sebagai berikut:

Tabel 3. Sebaran Deskriptif untuk Soal Latihan

\begin{tabular}{l|l|l|l|l|l|c|l}
\hline \multirow{2}{*}{ Tingkat Kognitif } & \multicolumn{6}{|c|}{ Soal Latihan (Ni) } & Total \\
\cline { 2 - 7 } & $\begin{array}{l}2.1 \\
\text { (Persamaan } \\
\text { Kuadrat) }\end{array}$ & $\begin{array}{l}2.2 \\
\text { (Grafik Fungsi } \\
\text { Kuadrat) }\end{array}$ & $\begin{array}{l}2.3 \\
\text { (Sumbu Simetri } \\
\text { dan titik } \\
\text { optimum) }\end{array}$ & $\begin{array}{l}2.4 \\
\text { (Menentukan } \\
\text { Fungsi Kuadrat) }\end{array}$ & $\begin{array}{l}2.5 \\
\text { (Aplikasi } \\
\text { Fungsi } \\
\text { Kuadrat) }\end{array}$ & $\begin{array}{l}\text { Persentase } \\
(\%)\end{array}$ \\
\hline C1-Mengingat & 0 & 0 & 0 & 0 & 0 & 0 & $0 \%$ \\
\hline C2-Memahami & 0 & 6 & 0 & 0 & 0 & 6 & $8,33 \%$ \\
\hline C3-Mengaplikasi & 18 & 12 & 14 & 10 & 7 & 61 & $84,72 \%$ \\
\hline C4-Menganalisis & 0 & 1 & 1 & 0 & 2 & 4 & $5,55 \%$ \\
\hline C5-Mengevaluasi & 0 & 0 & 0 & 0 & 1 & 1 & $1,4 \%$ \\
\hline C6-Mencipta & 0 & 0 & 0 & 0 & 0 & 0 & $0 \%$ \\
\hline Total & 18 & 19 & 15 & 10 & 10 & $\mathrm{~N}=72$ & $100 \%$ \\
\hline
\end{tabular}

Tabel 4. Sebaran Deskriptif untuk Soal Uji Kompetensi

\begin{tabular}{l|c|l}
\hline Tingkat Kognitif & Uji Kompetensi (Ni) & \multicolumn{1}{|c}{ Persentase } \\
\hline C1-Mengingat & 0 & $0 \%$ \\
C2-Memahami & 1 & $2,85 \%$ \\
C3-Mengaplikasi & 31 & $88,57 \%$ \\
C4-Menganalisis & 2 & $5,71 \%$ \\
C5-Mengevaluasi & 1 & $2,85 \%$ \\
C6-Mencipta & 0 & $0 \%$ \\
\hline Total & $\mathrm{N}=35$ & $100 \%$ \\
\hline
\end{tabular}

Deskripsi analisis tingkat kognitif soal latihan dan uji kompetensi berdasarkan taksonomi bloom revisi sebagai berikut:

\section{C2-Memahami (Soal Latihan 2.2 Grafik Fungsi Kuadrat nomor dua)}

"Dari soal 1, apa yang dapat kamu simpulkan mengenai grafik $y=\operatorname{ax}^{2}$ dengan $|a|<1$ dan $a \neq 0$ ?" 
Hasil analisis soal: Untuk menjawab soal ini, karena yang di minta kesimpulan dari grafik pada soal nomor 1 mengenai grafik $y=a^{2}$ dengan $|a|<1$ dan $a \neq 0$, maka:

1. Peserta didik perlu mengenali (C1) soal pada nomor 1

2. Peserta didik membandingkan (C2) terlebih dahulu soal 1a-1d, untuk melihat perbedaan dari grafik yang dihasilkan.

3. Peserta didik menafsirkan (C2) pola yang diberikan dari persamaan soal nomor 1a-1d dari grafik agar dapat menyimpulkan (C2) grafik $y=a x^{2}$ dengan $|a|<1$ dan $a \neq 0$. Karena dari soal 1a-1d perbedaannya terdapat pada nilai a yang lebih dari 0 dan kurang dari 0 , dan dapat disimpulkan (C2) ketika nilai atau grafiknya bernilai positif, maka grafik menghadap ke atas, atau bisa ditulis: Untuk $a>0$, grafik terbuka keatas dan untuk nilai $a$ yang bernilai negatif grafiknya menghadap ke bawah, atau bisa ditulis: Untuk $a<0$, grafik terbuka ke bawah. Lalu, peserta didik dapat menyimpulkan (C2) sendiri dari hasil yang diperoleh, yaitu untuk $a<0$ grafik terbuka ke bawah, dan untuk $a>0$ grafik terbuka keatas serta semakin nilai a menjauhi titik 0 dan mendekati 1/-1, maka grafik semakin lancip dan semakin nilai a mendekati titik 0 dan menjauhi $1 /-1$ maka grafik smakin tumpul.

Berdasarkan analisis tersebut, sesuai dengan indikator soal "memuat penjabaran mengenai sebab akibat antar informasi dalam satu system pada persamaan dan fungsi kuadrat". Sehingga, pada soal ini peserta didik berada pada kategori tingkat kognitif C2 yaitu "Memahami"

\section{C3-Mengaplikasikan (Soal Latihan 2.1 Persamaan Kuadrat nomor enam)}

“Jika nilai diskriminan persamaan kuadrat $3 \mathrm{x}^{2}-5 \mathrm{x}+\mathrm{c}=0$ adalah 49 , tentukan nilai c"

Hasil analisis soal: Pada soal ini, karena yang ditanya adalah nilai $c$ pada nilai diskriminan persamaan kuadrat $3 \mathrm{x}^{2}-5 \mathrm{x}+\mathrm{c}=0$ adalah 49 , maka:

1. Peserta didik mengingat (C1) rumus diskriminan yaitu $D=b^{2}-4 a c$.

2. Peserta didik memahami (C2) mana yang disebut $a, b$ dan $c$ pada persamaan kuadrat yang diketahui soal $3 \mathrm{x}^{2}-5 \mathrm{x}+\mathrm{c}=0$, dimana $a=3, b=-5, c=c$ dan nilai diskriminan atau $D$ adalah 49.

3. Peserta didik mensubstitusikan (C3) nilai yang diketahui tersebut ke rumus diskriminan $\left(49=(-5)^{2}-4.3 . c\right)$ lalu peserta didik mengalikannya $(49=25-12 c)$. Karena yang dicari adalah nilai $c$, maka peserta didik menghitung (C3) ruas kanan dan ruas kiri samasama dikurangi 25, yaitu: $49-25=25-25-12 c \rightarrow 24=-12 c$. Kemudian, ruas kanan dan ruas kiri sama-sama dibagi (C3) dengan -12 dan didapatlah nilai $c=-2$.

Berdasarkan analisis tersebut, sesuai dengan indikator soal pada "menjalankan proses suatu operasi hitung dengan penjumlahan, pengurangan, pembagian, perkalian dari persamaan dan fungsi kuadrat" soal tersebut didapat tingkat kognitifnya adalah C3 yaitu "mengaplikasikan"

\section{C4-Menganalisis (Soal Latihan 2.4 Aplikasi Fungsi Kuadrat nomor tujuh)}

"Seorang tukang bangunan mendapat pesanan membuat air mancur yang diletakkan di pusat kolam kecil yang berbentuk lingkaran. Pemesan menginginkan luas kolamnya adalah $10 \mathrm{~m}^{2}$. Jika tinggi maksimum dari air mancur adalah 2 meter dan air mancurnya harus jatuh tepat ditepian kolam maka tentukan persamaan kuadrat dari air mancur!" 
Hasil analisis soal: Untuk menyelesaikan soal ini, karena yang ditanya adalah persamaan kuadrat dari air mancur yang dibuat oleh seorang tukang bangunan yang mendapat pesanan membuat air mancur yang diletakkan di pusat kolam kecil yang berbentuk lingkaran dengan luas kolamnya adalah $10 \mathrm{~m}^{2}$, tinggi maksimum air mancur adalah $2 \mathrm{~m}$ dan air mancur tersebut harus jatuh ketepian kolam, maka:

1. Peserta didik mengenali (C1) bentuk penyajian soal ketika mengerjakan soal cerita, mengingat rumus yang diketahui seperti rumus luas lingkaran $\left(L=\pi r^{2}\right)$, bentuk umum persamaan kuadrat, dan rumus titik maksimum $\left(x_{p}, y_{p}\right)$.

2. Peserta didik menarik inferensi (C2) dari soal dengan mengilustrasikan sketsa gambar dari informasi soal yang diberikan, seperti bentuknya, ukurannya, dan titik koordinatnya.

3. Peserta didik memahami (C2) rumus luas lingkaran (air mancur yang ingin dibuat adalah berbentuk lingkaran) yaitu $L=\pi r^{2}$.

4. Luas lingkaran adalah $10 \mathrm{~m}^{2}$ dan $\pi=3,14$, peserta didik memasukkan (C3) nilai ke rumus luas lingkaran tersebut untuk diketahui berapa nilai $r$ atau jari-jari lingkaran.

5. Setelah di dapat jari-jari lingkaran yaitu $r=1,784$, peserta didik mendapatkan koordinat titik maksimum sementara yaitu di $(1 / 2 r, 2)$ (alasan didapat $1 / 2 r$ adalah jarak dari $(0,0)$ ke titik maksimumnya seperti pada gambar).

6. Selanjutnya, peserta didik menghitung (C3) nilai $b$ pada titik maksimum di $x_{p}=-\frac{b}{2 a^{\prime}}$, yaitu dengan mensubstitusikan nilai yang diketahui yaitu $1 / 2^{r}$ dengan $r=1,784$, menjadi $\frac{1}{2} \times 1,784=-\frac{b}{2 a}$ dan diperoleh nilai $b=-1,784 a$.

7. Kemudian mencari nilai $a$ pada titik maksimum $y_{p}=-\frac{D}{4 a}$, peserta didik mensubstitusikan (C3) nilai yang diketahui seperti $b=-1,784 a, c=0$ dan titik $y_{p}=2$. Menjadi $2=-\frac{(-1,784 a)^{3}-4 a(0)}{4 a}$. diperoleh $3,184 a^{2}+8 a=0$.

8. Peserta didik menghitung (C3) berapa persamaan nilai a menggunakan metode pemfaktoran, seperti $a(3,184 a+8 a)=0$, dengan $a=0$ atau $3,184 a+8=0$.

9. Pada persamaan $3,184 a+8=0$, diperoleh nilai $a=-2,512$, peserta didik mensubstitusikan (C3) nilai $a=-2,512$ ke $b=-1,784 a$, dan diperoleh nilai $b=4,481$.

10. Setelah diperoleh nilai $a=-2,512$, nilai $b=4,481$ dan $c=0$, peserta didik menggabungkan atau memasukkanmenjadi bentuk umum persamaan kuadrat, diperoleh bentuk umum persamaan kuadrat adalah $f(x)=-2,512 x^{2}+4,481 x$

11. Peserta didik mengorganisasikan (C4) beberapa rumus yang tidak dipelajari dibab ini seperti luas lingkaran (bukan di bab ini).

Berdasarkan analisis di atas, sesuai dengan indikator soal pada mengorganisasi yaitu "menggabungkan beberapa konsep atau rumus yang muncul dari informasi data" sehingga soal ini berada pada tingkat kognitif C4 yaitu "Menganalisis"

\section{C5-Mengevaluasi (Soal Uji Kompetensi nomor enam belas)}

"Analisis kesalahan. Lily menentukan fungsi kuadrat yang memiliki akar $\mathrm{x}=3$ dan $\mathrm{x}=-2$ serta grafiknya melalui titik koordinat $(0,12)$. Fungsi kuadrat yang diperoleh adalah $y=-2 x^{2}-2 x+12$. Tentukan kesalahan yang dilakukan oleh Lily." 
Hasil analisis soal: Untuk menyelesaikan soal ini, karena yang ditanya adalah menentukan kesalahan dari fungsi kuadrat yang memiliki akar $\mathrm{x}=3$ dan $\mathrm{x}=-2$ serta grafiknya melalui titik koordinat $(0,12)$ dan fungsi kuadrat yang diperoleh adalah $y=-2 x^{2}-2 x+12$, maka:

1. Peserta didik mengingat kembali (C1) bentuk umum persamaan kuadrat $f(x)=a x^{2}+b x+c$.

2. Peserta didik memahami (C2) persamaan kuadrat memiliki 2 akar, seperti disebutkan pada soal bahwa akar-akarnya yaitu pada $x=3$ dan $x=-2$.

3. Peserta didik mengubah (C3) akar-akar $x=3$ dan $x=-2$ menjadi pemfaktoran $(x-3)(x+2)$, lalu dikalikan untuk membentuk persamaan kuadrat, $y=x^{2}-x-6$.

4. Peserta didik memahami $(\mathrm{C} 2)$ titik koordinat $(0, y)$ adalah itik yang memotong pada sumbu $y$, seperti pada titik $(0,12)$.

5. Lalu peserta didik mensubstitusikan (C3) titik grafik yang di lalui pada titik koordinat $(0,12)$ ke persamaan $f(0)=a(0)^{2}+b(0)+c$ dan di dapat $c=12$.

6. Karena $c=12$, maka peserta didik mengalikan (C3) persamaan $-x^{2}+x+6=0$ dikali 2 menjadi $-2 x^{2}+2 x+12=0$.

7. Peserta didik membedakan (C4) persamaan kuadrat yang diperoleh dari hasil pencarian dengan persamaan kuadrat yang di dapat dari soal (antara $-2 x^{2}+2 x+12=0$ dengan $\left.y=-2 x^{2}-2 x+12\right)$.

8. Selanjutnya, peserta didik memeriksa (C5) kesalahan dari persamaan $-2 x^{2}+2 x+12=0$ dengan $y=-2 x^{2}-2 x+12$, ternyata kesalahannya pada nilai $b$ yaitu -2 , yang benarnya adalah $b=2$

Berdasarkan analisis tersebut, soal ini sesuai dengan indikator soal memeriksa "pembuktian cara lain suatu stuktur dengan menggunakan berbagai penyelesaian" dan berada pada tingkat kognitif C5 yaitu "Mengevaluasi"

Hasil analisis tingkat kognitif soal antara peneliti dan teman sejawat memiliki kesesuaian. Namun hal itu bukan berarti hasil analisis tingkat kognitif soal antara peneliti dan teman sejawat sama dan serupa. Rekapan perbedaan dapat dilihat pada Tabel 4.3 sebagai berikut:

Tabel 5. Hasil Rekapan Kesesuaian Analisis Tingkat Kognitif Soal Persamaan dan Fungsi Kuadrat dengan Teman Sejawat

\begin{tabular}{|c|c|c|c|}
\hline \multirow{2}{*}{$\begin{array}{c}\text { No. Soal } \\
\text { (pertanyaan) }\end{array}$} & \multicolumn{2}{|c|}{ Hasil } & \multirow{2}{*}{$\begin{array}{c}\text { Kategori dari peneliti ke } \\
\text { teman sejawat }\end{array}$} \\
\hline & Peneliti & Teman Sejawat & \\
\hline \multicolumn{4}{|c|}{ Latihan 2.1 Persamaan Kuadrat } \\
\hline 7 & C3 & $\mathrm{C} 2$ & Menurun \\
\hline 10 & $\mathrm{C} 3$ & $\mathrm{C} 2$ & Menurun \\
\hline \multicolumn{4}{|c|}{ Latihan 2.2 Grafik Fungsi Kuadrat } \\
\hline 6 & $\mathrm{C} 4$ & $\mathrm{C} 2$ & Menurun \\
\hline \multicolumn{4}{|c|}{ Latihan 2.5 Aplikasi Fungsi Kuadrat } \\
\hline 6 & C5 & $\mathrm{C} 4$ & Menurun \\
\hline 8 & $\mathrm{C} 3$ & $\mathrm{C} 4$ & Menaik \\
\hline \multicolumn{4}{|c|}{ Uji Kompetensi 2} \\
\hline 17 & C3 & $\mathrm{C} 4$ & Menaik \\
\hline 30 & $\mathrm{C} 3$ & $\mathrm{C} 4$ & Menaik \\
\hline \multicolumn{2}{|c|}{ Persentase perbedaan analisis } & $6,54 \%$ & \\
\hline
\end{tabular}


Hasil analisis tingkat kognitif soal latihan dan uji kompetensi yang dilakukan oleh peneliti dan teman sejawat dilihat korelasinya dengan menggunakan perhitungan uji spearman rank menggunakan SPSS (Lampiran 7). Kemudian, diperoleh hasil korelasi antara peneliti dengan teman sejawat sebesar "0,721" yang menunjukkan bahwa terdapat hubungan yang kuat dan signifikan (1-ekor) antara hasil analisis tingkat kognitif peneliti dengan teman sejawat. Sehingga, dapat peneliti katakan bahwa hasil analisis tingkat kognitif yang dilakukan oleh peneliti dengan teman sejawat sangat baik atau sesuai dengan lembar acuan yang di inginkan. Soal soal dengan tingkat kognitif yang berbeda perlu dianalisis kembali tingkat kognitifnya berdasarkan Taksonomi Bloom revisi

\section{Pembahasan}

Suatu sebaran tingkat kognitif dikatakan baik yaitu berada pada rata-rata tingkat kognitif C1-mengingat sebesar 5\%, C2-memahami sebesar 10\%, C3-mengaplikasikan sebesar 45\%, C4menganalisis sebesar 25\%, C5-mengevaluasi sebesar 10\%, dan C6-mencipta sebesar 5\% (Helmawati, 2019). Selain itu, soal yang baik adalah soal yang tidak terlalu mudah dan tidak terlalu sulit yang dimaksudkan adalah dalam aplikasinya soal-soal yang diberikan kepada peserta didik haruslah mempertimbangkan tingkat kognitif pada taksonomi Bloom revisi agar soal dapat membantu mengembangkan peserta didik (Bagiyono, 2017).

\section{Pembahasan Hasil Analisis Tingkat Kognitif Soal Latihan}

Berdasarkan hasil analisis yang dilakukan, untuk soal Latihan materi Persamaan dan Fungsi Kuadrat pada Buku Sekolah Elektronik Matematika Kelas IX SMP/MTs edisi Revisi 2018 terbitan Kemendikbud ini memuat sedikit tingkat kognitif C5-mengevaluasi dan C4menganalisis, serta tidak ditemukannya soal yang termasuk kedalam tingkatan kognitif C1mengingat dan C6-mencipta. Sedangkan tingkat kognitif C3-mengaplikasikan paling mendominasi.

Soal pada tingkat kognitif C1-mengingat tidak ditemukan. Padahal, salah satu Kompetensi Dasar pada buku BSE ini menyebutkan tentang "Menyajikan fungsi kuadrat menggunakan tabel, persamaan, dan grafik". Hal ini bisa dimasukkan soal-soal berupa mengingat kembali bagaimana fungsi kuadrat atau mengenali grafik fungsi kuadrat, dan lainlain. Namun, tidak ada satupun soal yang demikian. Sehingga, seharusnya pada sub bab 2.2 Grafik Fungsi Kuadrat bisa di masukkan soal C1-mengingat seperti yang dikemukakan Masduki, M.R. Irawan, \& D.Y. Prihantoro. A., (2013) bahwa kemampuan matematika peserta didik di Indonesia berada mulai dari tingkatan terendah yaitu pada tingkat kognitif mengetahui/knowing karena peserta didik Indonesia belum dapat secara baik menerapkan kemampuan dan pengetahuan dasar yang dimiliki untuk menyelesaikan masalah/applying serta belum menerapkan pengetahuan yang lebih kompleks lagi seperti menyusun strategi/reasoning. Begitu pula berpengaruh kepada tingkat kognitif C6 atau menengah dan tinggi, rendahnya kemampuan peserta didik berdampak pada tujuan pembelajaran dan penilaian yang dilakukan oleh pendidik (Fatonah, 2005: 12). Singkatnya, soal dengan tingkat kognitif C6-mencipta tidak ditemukan satu soal pun, padahal untuk mencapai taraf proporsional tingkat kognitif C6 yaitu sebesar 5\% seperti peneliti mengambil konsep dari Helmawati (2019) yaitu pada rata-rata tingkat kognitif C1-mengingat sebesar 5\%, C2memahami sebesar 10\%, C3-mengaplikasikan sebesar 45\%, C4-menganalisis sebesar 25\%, C5- 
mengevaluasi sebesar 10\%, dan C6-mencipta sebesar 5\% untuk melatih peserta didik dengan keterampilan yang lebih tinggi.

Selain itu, soal dengan tingkat kognitif C5-mengevaluasi hanya terdapat 1 soal saja karena soal ini mengarahkan peserta didik untuk memeriksa kembali dan mengkritisi soal yang diberikan yang sebagian besarnya soal pada tingkat kognitif ini perlu di evaluasi hasil yang diperoleh dengan hasil yang disebutkan pada soal. Sedangkan tingkat kognitif C3mengaplikasikan mendominasi dengan sebanyak 61 pertanyaan yang ditemukan pada tingkat tersebut, karena sebagian besar menentukan suatu persamaan dan fungsi kuadrat yang sudah ada rumusnya. Maka tidak heran jika soal yang ditemukan mayoritas berada pada tingkat kognitif C3-mengaplikasikan yang hal ini sesuai dengan pernyataan Kemendikbud, (2013) yang menyatakan bahwa tingkat kognitif pada jenjang sekolah menengah pertama mencapai tingkat kemampuan C3-menerapkan/mengaplikasikan dan C4-menganalisis, meskipun pada tingkat kognitif C4-menganalisis masih sedikit yakni sebesar 5,55\%.

Standar proporsi pada tingkat kognitif soal yang diteliti masih berbeda dengan proposi pada tingkat kognitif minimal standar, hal ini disebabkan karena soal-soal yang diberikan sebagian besar mengarahkan peserta didik untuk menjalankan rumus atau menghitung operasi (C3-mengaplikasikan) yang berkaitan dengan materi persamaan dan fungsi kuadrat. Sedangkan, hanya sebagian kecil seperti yang dijelaskan sebelumnya belum sesuai dengan standar proporsinya. Namun, untuk setiap subbab yang diberikan sudah sesuai dengan materi atau contoh soal yang diberikan pada Buku Sekolah Elektronik (BSE) Matematika.

\section{Pembahasan Hasil Analisis Tingkat Kognitif Soal Uji Kompetensi}

Hasil analisis yang dilakukan ini memuat sedikit tingkat kognitif C2-memahami dan tingkat kognitif C5-mengevaluasi, serta tidak ditemukannya soal yang termasuk kedalam tingkatan kognitif C1-mengingat dan C6-mencipta. Sedangkan tingkat kognitif C3mengaplikasikan paling mendominasi, hal ini terlihat bahwa soal uji kompetensi pada tingkat kognitif belum semuanya ada.

Sama halnya dengan soal Latihan, soal Uji Kompetensi ini belum ditemukannya soal pada tingkat kognitif C1-mengingat. Padahal, seharusnya ada beberapa soal untuk membuat peserta didik memulai dengan kategori atau tingkat kognitif yang paling rendah. Pada soal dengan tingkat kognitif C6-mencipta juga tidak ditemukan dan belum sesuai dengan standar proporsional yaitu pada tingkat kognitif C6 yaitu sebesar 5\% seperti peneliti mengambil konsep dari Helmawati (2019) yaitu pada rata-rata tingkat kognitif C1-mengingat sebesar 5\%, C2memahami sebesar 10\%, C3-mengaplikasikan sebesar 45\%, C4-menganalisis sebesar 25\%, C5mengevaluasi sebesar 10\%, dan C6-mencipta sebesar 5\%. Selain itu, soal dengan tingkat kognitif C2-memahami dan C5-mengevaluasi masing-masing hanya terdapat 1 soal saja karena soal ini mengarahkan peserta didik untuk menyimpulkan (pada C2), memeriksa kembali dan mengkritisi (pada C5) soal yang diberikan yang sebagian besar soal pada tingkat kognitif ini perlu mengevaluasi hasil yang diperoleh dengan hasil yang disebutkan pada soal. Sedangkan tingkat kognitif C3-mengaplikasikan mendominasi dengan sebanyak 31 pertanyaan yang ditemukan pada tingkat tersebut, karena sebagian besar menentukan dan menjalankan rumus seperti menentukan persamaan kuadrat baru, menentukan nilai pada suatu variabel, menentukan akar persamaan kuadrat, menggambar atau mensketsa grafik fungsi kuadrat, mencari fungsi kuadrat dari titik koordinat yang diketahui arau menentukan titik potong, menentukan sumbu simetri, dan soal cerita tentang persamaan dan fungsi kuadrat. Maka tidak heran jika soal yang ditemukan mayoritas berada pada tingkat kognitif C3-mengaplikasikan 
yang hal ini sesuai dengan pernyataan Kemendikbud (2013) yang menyatakan bahwa tingkat kognitif pada jenjang sekolah menengah pertama mencapai tingkat kemampuan C3menerapkan/mengaplikasikan dan C4-menganalisis, meskipun pada tingkat kognitif C4menganalisis masih sedikit yakni sebesar 5,71\% tidak jauh berbeda dengan soal Latihan.

Pada sisi yang lain, soal Uji Kompetensi materi Persamaan dan Fungsi Kuadrat sudah dibuat sesuai dengan Kompetensi Dasar dan diambil dari materi di setiap subbab. Tetapi, hanya perlu ditambah lagi soal yang bervariasi agar memenuhi tingkat kognitif C1-memahami hingga C6-mencipta sesuai dengan teori yang telah disebutkan. Hal ini dilakukan agar pengajar (guru) dapat memberikan soal berupa evaluasi kepada peserta didik agar guru dapat mengetahui perkembangan peserta didik dari soal-soal yang bervariasi berdasarkan taksonomi Bloom revisi dalam berpikir kritis, dan dapat menyelesaikan masalah yang ada disekitarnya.

Berdasarkan penjelasan, dapat disimpulkan bahwa tingkat kognitif pada soal uji kompetensi belum cukup proporsional karena pada tingkat kognitif C1-mengingat dan C6mencipta bernilai nol (0\%) yang artinya kurang dari 5\%, C2-memahami dan C5-mengevaluasi tidak sampai $10 \%$ yaitu 2,85\%, C4-menganalisis juga tidak sampai $25 \%$ yaitu hanya 5,71\%, sedangkan C3-mengaplikasi lebih dari 45\% yaitu 88,57\%. Oleh karena itu, sebaiknya soal-soal uji kompetensi materi Persamaan dan Fungsi kuadrat pada Buku Sekolah Elektronik (BSE) Matematika edisi Revisi 2018 kelas IX ini memuat sebaran tingkatan kognitif yang bervariasi lagi dengan menambah soal dengan tingkat kognitif yang masih kurang agar mencapai makna proporsional.

\section{Simpulan}

Berdasarkan hasil dan pembahasan analisis tingkat kognitif soal Persamaan dan Kungsi Kuadrat pada Buku Sekolah Elektronik (BSE) Matematika kelas IX SMP terbitan Kemendikbud edisi revisi 2018, maka dapat disimpulkan sebagai berikut:

1. Pada soal-soal Latihan, setelah dilakukan analisis terhadap tingkat kognitifnya dengan soal sebanyak 72 pertanyaan diperoleh soal-soal Latihan ini memuat tingkat kognitif C2 (Memahami) sebanyak 6 pertanyaan (8,33\%), tingkat kognitif C3 (Mengapikasikan) sebanyak 61 pertanyaan (84,72\%), tingkat kognitif C4 (Menganalisis) sebanyak 4 pertanyaan (5,55\%), dan tingkat kognitif C5 (Mengevaluasi) sebanyak 1 pertanyaan (1,4\%). Sedangkan tidak ada satupun pertanyaan pada tingkat kognitif C1 (Mengingat) dan tingkat kognitif C6 (Mencipta). Sehingga, diketahui bahwa sebaran tingkat kognitif soal Latihan 2.1 sampai Latihan 2.5 belum proporsional.

2. Pada soal Uji Kompetensi, setelah dilakukannya analisis terhadap tingkat kognitif soal berdasarkan taksonomi Bloom revisi maka diperoleh soal Uji kompetensi ini memuat tingkat kognitif C2 (Memahami) sebanyak 1 pertanyaan (2,85\%), tingkat kognitif C3 (Mengapikasikan) sebanyak 31 pertanyaan (88,57\%), tingkat kognitif C4 (Menganalisis) sebanyak 2 pertanyaan (5,71\%), dan tingkat kognitif C5 (Mengevaluasi) sebanyak 1 pertanyaan $(2,85 \%)$. Sedangkan tidak ada satupun pertanyaan pada tingkat kognitif C1 (Mengingat) dan tingkat kognitif C6 (Mencipta). Hal ini sama dengan soal Latihan. Sehingga, diketahui bahwa sebaran tingkat kognitif soal uji kompetensi masih belum proporsional.

\section{Saran}


Berdasarkan penelitian yang telah dilaksanakan oleh peneliti, terdapat beberapa saran, yaitu sebagai berikut:

1. Penelitian ini hanya mencakup 1 bab materi saja, yaitu Persamaan dan Fungsi Kuadrat dari keseluruhan 5 bab dalam Buku Sekolah Elektronik (BSE) Matematika kelas IX, sehingga bagi peneliti lain yang ingin meneliti dapat ditambahkan lagi beberapa bab materi dan pembahasannya.

2. Bagi guru atau pengajar sebaiknya memilih terlebih dahulu soal-soal latihan dan uji kompetensi materi persamaan dan fungsi kuadrat ini berdasarkan tingkat kognitifnya sebelum diberikan kepada peserta didik agar pengajar bisa melihat potensi pemahaman peserta didiknya.

Bagi peneliti lain, diharapkan untuk mengatur waktu ketika penelitian, karena penelitian analisis soal ini membutuhkan waktu yang cukup lama.

\section{Daftar Rujukan}

Amelia, D., Susanto, S., \& Fatahillah, A. (2016). Analisis Hasil Belajar Matematika Siswa Pada Pokok Bahasan Himpunan Berdasarkan Ranah Kognitif Taksonomi Bloom Kelas VII-A di SMPN 14 Jember. Jurnal Edukasi, 2(1), 1. https://doi.org/10.19184/jukasi.v2i1.3402

Anderson, L. W., \& Krathwohl, D. R. (2010). Kerangka Landasan Untuk Pembelajaran, Pengajaran, dan Asesmen. (terjemahan) (1 ed.). Yogyakarta; Pustaka Pelajar.

Bagiyono. (2017). Analisis Tingkat Kesukaran dan Daya Pembeda Sial Ujian Pelatihan Radiografi Tingkat 1. Widyanuklida, 16(No. 1), 1-12. http://reponkm.batan.go.id/140/1/05_analisis_tingkat_kesukaran.pdf

BSNP. (2014). Instrumen Penilaian Buku Teks Pelajaran Pendidikan Dasar dan Menengah.

Fatonah, S. (2005). Aplikasi Aspek Kognitif (teori bloom) dalam Pembuatan Soal Kimia. Kauni, $1(2)$.

Helmawati. (2019). Pembelajaran dan Penilaian Berbasis HOTS. ROSDA.

Kemendikbud. (2013). Peraturan Mendikbud Nomor 58 tahun 2014 tentang Kurikulum 2013 Sekolah Menengah Pertama (SMP)/ Madrasah Tsanawiyah (MTs).

Kurniawan, T. (2020). Analisis Soal Buku Matematika Kelas VII Edisi Revisi 2017 pada Materi Penyajian Data Berdasarkan Taksonomi Bloom. JP2MS.

Masduki, S., M.R., I., \& D.Y.A., P. (2013). Level Kognitif soal-soal Pada Buku Teks Matematika SMP Kelas VII. diseminarkan pada Seminar Nasional Matematika dan Pendidikan Matematika FMIPA UNY.

Mullis, I. V. S., Martin, M. O., Foy, P., Kelly, D. L., \& Fishbein, B. (2012). TIMSS 2011.pdf. TIMSS \& PIRLS International Study Center.

Puryati, E. (2017). MENINGKATKAN HASIL BELAJAR SISWA DENGAN. VI(2), 192-201.

Riduwan. (2014). Pengantar Statistika Sosial. Bandung: Alfabeta.

Sugiyono. (2019a). Metode Penelitian Kuantitatif Kualitatif dan RED (Sutopo (ed.)). Bandung: Alfabeta.

Sugiyono. (2019b). Statistika untuk Penelitian (30 ed.). Bandung: Alfabeta. 
Wu, M. (2009). A critical comparison of the contents of PISA and TIMSS mathematics assessments. Mebourne : Faculty of Education. 